\title{
VERSOLIBRISMO Y REGULARIDAD MÉTRICA: LA «FORMA LIBRE» DE JUAN RAMÓN JIMÉNEZ
}

\author{
Fernando Gómez Redondo
}

Universidad de Alcalá de Henares

\section{CONSIDERACIONES PREVIAS: LA REGULARIDAD MÉTRICA Y EL VERSO LIBRE}

No es ajeno el versolibrismo a la regularidad métrica. Salvo casos contados, el poeta accede al verso libre desde el dominio previo de los esquemas regulares, desde la asunción de unos moldes métricos que implican la asimilación de unas secuencias de pensamiento poético; la indagación que promueve la poesía versolibrista se abre a orientaciones conceptuales enteramente nuevas, ligadas como lo están al acto mismo de la creación, al desvelamiento de unas cláusulas rítmicas que han de reproducir el estado emocional que padece el poeta; absorbida la dimensión (puramente intelectiva) que encierra el isosilabismo, el poeta ensaya otras manifestaciones en que su decir poético es conducido a diferentes órdenes de expresividad: porque siempre hay un 
«orden», desde el momento en que las palabras logran acompasar el ilógico proceso del que surge la disposición versal ${ }^{1}$.

El versolibrismo no es tan libre como pudiera pretender la adjetivación que lo señala. Como todo acto de creación poética, ha de estar sujeto si no a una preceptiva, sí a unas normas propias de «regulación formal», posiblemente aplicables a un solo acto creador, pero tan firmes y reales como la materia poética que ha logrado entramarse en ese proceso de construcción poemática.

Todo poema, ya guiado por equivalencias métricas, ya orientado hacia dimensiones de libertad formal, implica una violentación de las pautas de ordenación, de las rutinas expresivas de la lengua estándar. Cada poema inventa su lenguaje, ajusta la selección de paradigmas y la combinación de sintagmas a la configuración rítmica de la que surge ${ }^{2}$. El poema es más poesía en tanto en cuanto construya una visión del mundo vinculada a una específica manera de nombrar y de decir, por tanto de pensar.

Un poeta, ya en verso regular o libre, desde la poesía a la que accede con sus poemas, con sus poemarios, levanta una teoría poética que es consecuencia primero de ese enfrentamiento con la realidad del lenguaje en la que habita, después de la revelación - siempre sorprendente- de ese ilimitado dominio de ser y de existir al que ha llegado ${ }^{3}$.

Lo que ya no resulta tan fácil es que logre regular el proceso de su creación conforme a los dictados de esa poética que ha ido ensayando y confirmando en cada acto creador. Cuando ello ocurre, cuando el poeta se convierte en crítico de su especial decir, las posibilidades de analizar el frágil fenómeno de la construcción poemática son extraordinarias. Tal es lo que sucede con Juan Ramón Jiménez; desde sus primeros poemas de 1896 hasta que comienza a construir el Diario que habría de llevarlo, por su primer mar, hasta Nueva York, Juan Ramón pulsa todos los registros formales de la creación poética, se adentra en

1 Resumo aquí aspectos de los que me he ocupado en «Verso regular y verso libre», en Gómez Redondo (1994: 65-78). Por supuesto, son nociones que han de ampliarse con «9.4. Verso libre», de Domínguez Caparrós (1993: 183-190), amén de un amplio abanico de estudios que convergen, ahora, en Domínguez Caparrós (1999a).

2 «El problema de la relación entre verso y lenguaje se centra en la adecuación del verso al lenguaje, o en la resistencia que el lenguaje ofrece al verso», como indica Domínguez Caparrós (1988: 83).

3 «El mundo cósico cambia de naturaleza en la obra del hombre mediante la palabra poética. Y esto es el poema, un «lenguaje erguido», una obra que funde al hombre y a la palabra en unidad autosuficiente», señala Antonio Domínguez Rey (1987: 145). 
cualquiera de las corrientes literarias de las que tiene noticia, se adueña, en fin, de unos procedimientos de «regulación» formal que convertirá en soporte de posteriores indagaciones poemáticas, sean éstas de la índole que sean ${ }^{4}$.

Y esta circunstancia es especialmente oportuna porque permite valorar la supuesta paradoja que en este trabajo se presenta: el análisis de las secuencias de regularidad métrica insertas en la creación versolibrista, un hecho que no resulta casual, sino que obedece a precisas razones de ejecución poética ${ }^{5}$. Es más: no hay mejor modo de analizar un poema versolibrista que valorar los esquemas rítmico-silábicos con que los versos se construyen y se anudan en núcleos estróficos; la identidad del verso depende del modo en que los impulsos rítmicos han logrado articular períodos marcados por una misma equivalencia métrica (verso regular) o disponer series abiertas de combinación silábica (verso libre) que no por ello dejan de estar sometidas a pautas o a procesos de específica «regularidad» formal ${ }^{6}$. El verso, en todo momento, tiene que quebrar los límites lógicos y racionales de la lengua estándar, está obligado a generar pautas particulares de «regulación» expresiva, líneas propias de adentramiento en el orden de realidad formal que depende de ese específico acto del lenguaje poético ${ }^{7}$.

\section{LA CRÍTICA POEMÁTICA DE JUAN RAMÓN: EL VERSOLIBRISMO DE DIARIO}

Juan Ramón, por sus observaciones teóricas y por su ejecución poemática, permite descubrir claves de un pensamiento creador muy riguroso que propicia una de las más felices aproximaciones que pudiera

${ }^{4}$ Resumo aquí planteamientos esbozados en Gómez Redondo (1996).

5 J. Domínguez Caparrós señala un proceso similar en el caso de Rubén Darío: «Lo que está claro es que formas de versificación como la que intenta imitar el hexámetro clásico, la de cláusulas o la libre, confluyen en la creación de un espacio nuevo, al margen del isosilabismo tradicional, y esto explica el que se dude, a veces, en la calificación concreta de un poema», en Domínguez Caparrós (1999b: 45-66, 53).

6 Por ello, Tomás Navarro Tomás (1974: 455) distinguía entre versificación libre y semilibre, indicando: «No hay en realidad composición versolibrista que no ofrezca casos de esta especie identificables con versos y estrofas regulares. La proporción de tales casos, que en la versificación semilibre actúa como tónica dominante, se reduce aquí, por el contrario, a manifestaciones escasas y aisladas».

7 Resume magistralmente Jean Cohen (1977: 103): «El verso no saca partido del defecto de la lengua sino a condición de agravarlo». 
plantearse en torno a la aparente libertad del versolibrismo; la oportunidad de su ejemplo es extraordinaria por el magisterio que ejerce tras su regreso de Moguer en 1912, en especial desde el otoño de 1913 en que se traslada a la Residencia de Estudiantes ${ }^{8}$; este período de búsqueda y de reflexión, en el que su creación sigue ajustada a la periódica pauta de los libros, conduce a ese desbordante proceso de pensamiento poético del que surge el Diario de un poeta reciencasado; las novedades de este poemario, en el que se encontraba ya en ciernes su Obra entera, las señalaba, en atinado ejercicio de crítica paralela, el propio poeta:

Yo venía escribiendo por el mar mi diario, que publiqué a mi vuelta a Madrid, con Estio, Sonetos espirituales y Platero. El Diario fue saludado como un segundo primer libro mío y el primero de una segunda época. Era el libro en que yo soñaba cuando escribía Ninfeas; era yo mismo en lo mismo que yo quería. $Y$ determinó una influencia súbita y benéfica en los jóvenes españoles e hispanoamericanos, y la burla de todos los césares de España. La crítica mayor y mejor está de acuerdo en que con él comenzó una nueva vida en la poesía española (un «gran incendio» poético, dijo uno). En realidad, el Diario es mi mejor libro. Me lo trajeron unidos el amor, el alta mar, el alto cielo, el verso libre, las Américas distintas y mi largo recorrido anterior. Es un punto de partidas $(1981: 174)^{9}$.

Cuando Juan Ramón afirma que el Diario es su mejor libro, posee ya la perspectiva crítica suficiente, amén de la distancia temporal, para hacerlo; y esa valoración del año de 1945 lo que pone de manifiesto es que en ese poemario se encontraban implícitas las pautas a las que habría de ajustar el restante proceso de una creación que se disponía a abandonar ya la fragmentaria condición del libro, para entramar, por fin, las plurales líneas — «el amor, el alta mar, el alto cielo, el verso libre»- de la que llamaría Obra, sólo revelada, en su inmensidad, en Animal de fondo (convertido, enseguida, en Dios deseante y deseado).

Diario se asienta, pues, en la exploración del versolibrismo, lo que no significa que sea contrario a los procesos de «regulación» formal, incluyendo los métricos; en cualquiera de sus poemas, hay impulsos

${ }^{8}$ Recuerda Carlos Bousoño (1970: 294): «Esto sin olvidar la utilización del versículo, que antes de Juan Ramón Jiménez sólo había tenido desmañados y escasos ensayos en español. De este modo, Juan Ramón Jiménez completa o casi completa el repertorio de los usos poéticos, que alcanzarán un máximo de vigencia y frecuentación en la generación siguiente, la de 1927, donde todos ellos proliferarán en abundancia y con plenitud».

9 Se trata de «El modernismo poético en España e Hispanoamérica», texto publicado en 1946. 
rítmicos que acaban fijando secuencias de ordenación silábica, porque reproducen el acompasado movimiento de su conciencia poética; los heptasílabos, los eneasílabos pero, sobre todo, los endecasílabos predominan en esta heterogénea manifestación de regularidades versales; véase, de muestra, el n. ${ }^{\circ}$ VI, «Soñando», surgido de la madrugada del 21 de enero, en el tren que lo alejaba de Madrid ${ }^{10}$ :

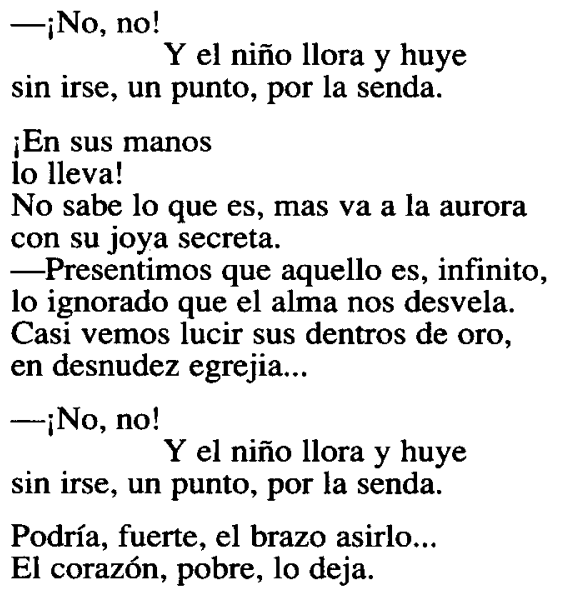

o óo óo óo óo (eneasíl. trocaico)

o óo óo òo óo (eneasíl. trocaico)

oo óo

o óo

5 o óo óo óo óo óo (endecasíl. trocaico) o òo òo óo (heptasíl. trocaico) oo óoo óo òo óo (endecasíl. mixto) oo óoo óo òo óo (endecasíl. mixto) oo óoo óo óo óo (endecasíl. mixto)

10 o òo óo óo (heptasíl. trocaico)

o óo óo óo óo (eneasíl. trocaico) o óo óo òo óo (eneasíl. trocaico)

o óo óo óo óo (eneasíl. trocaico) o òo óo óo óo (eneasíl. trocaico)

Salvo los versos 3 y 4 (aunque su suma da un heptasílabo ${ }^{11}$ ), el resto del poema es una «libre» disposición de esquemas regulares, algunos quebrados como en los versos primero y undécimo, pero ajustados perfectamente a unos procesos de ordenación silábica, en los que alternan las secuencias de siete, de nueve y de once sílabas, con las que Juan Ramón va a «regular» la mayor parte de sus poemas versolibristas.

No se trata de un poema en verso regular, por supuesto, pero sólo deja atrapar sus significados cuando es analizado desde perspectivas de regulación métrica. El número de versos de que consta el poema es fundamental para captar el juego de intenciones que en el mismo se dispone; son catorce versos, porque los dos partidos (vv. 1 y 11) cuentan como uno solo ${ }^{12}$; ese proceso de distribución versal es necesario

10 Cito por la ed. A. Sánchez-Barbudo (1994: 70). En los análisis rítmicos distingo cláusulas trocaicas $(o ́ o)$ y dactílicas (óoo) conforme los criterios marcados por T. Navarro Tomás (1974: 36-37).

11 Ya señalaba, con un ejemplo de J.R. Jiménez, F. López Estrada (1969: 125) que, en las líneas poéticas breves, «suele encontrarse la poesía condensada, en la que apuntan rasgos del sentido popular».

12 A pesar de lo obvio de esta observación, no sucede así en la ed. cit. de A. Sánchez Barbudo, quien dispone tipográficamente un poema con dieciséis versos. 
para reparar en la asonancia (é- $a$ ) con que los versos pares resultan enlazados; la presencia de la rima es otro fenómeno que advierte sobre las «regularidades» con que el versolibrismo puede construir esquemas de ordenación rítmica, que aprovechen cualquier recurso de ruptura con respecto a la lengua estándar; en este caso, el ritmo trocaico gobierna la secuencia poemática en todo su transcurso, menos en el bloque central de los tres endecasílabos (vv. 7-9), en los que se expande el desconocimiento, la incertidumbre manifestada en el v. $5^{13}$, en una tensa contradicción que esos tres versos recorren mediante la nueva secuencia rítmica que impone el dáctilo marcado en la sílaba tercera; se conectan así los términos centrales con que se accede a ese descubrimiento de la realidad poética: dos verbos («Presentimos», $v$. 7, «casi vemos», v. 9) que atrapan en su interior esa noción de un misterio poético que ha de hacerse nuevo («lo ignorado», v. 8), en cuanto el poeta logre conectar los términos que le permitan acceder a ese grado de realidad; ésta es la circunstancia que exige la presencia de la «regularidad» formal en un poema para el que se reconoce una orientación versolibrista; los esquemas isosilábicos resultan piezas esenciales de la disposición de paradigmas que en el texto se alcanza:

Presentimos que-aquello-es infinito, lo-ignorado que-el alma nos desvela.

Casi vemos lucir sus dentros de-oro,

Hay un triángulo de conexiones en este bloque central que gira sobre esa asonancia ( «desvela»: la acción que está a punto de ocurrir) y que vincula la idea de lo «infinito» (en la que se entreabre la dimensión de «eternidad» que, ya a partir de este mismo año, irá entregando a un específico poemario) con la noción de «lo ignorado» (ese mundo interior de renovación poética que en ese viaje que está a punto de iniciar se convertirá en real certidumbre) con, finalmente, esos «dentros de oro» (una imagen que sintetiza la dimensión de «belleza» - pero ya interna: «desnudez»— que comenzará a recorrer a partir de ese año). Repárese, además, en que la noción de lo «infinito» se encuentra dispuesta en el verso medial del poema.

Toda esta dimensión interpretativa es descubierta en cuanto se presta atención a esos esquemas de regularidad formal que siguen

13 Repárese en la progresión acentual de un verso en que tres verbos («no saber», «ser», «ir») son enlazados acentualmente para proyectarlos en un sustantivo, que se convierte en el paradigma de la indagación de este poema. 
siendo operativos, a pesar de la consciente dimensión versolibrista con que Juan Ramón accede a este distinto horizonte con que la poesía se adentra en las nuevas orientaciones a que el poeta conduce su vida.

\section{CONTENIDO POEMÁTICO Y VERSOLIBRISMO}

Verso libre, en el caso de Juan Ramón y en el de la promoción de poetas que arranca de su continua experimentación, no significa, entonces, una abolición de la forma, una renuncia a la secuencia métrica, sino el único medio de alcanzar esa «desnudez» (v. 10) que permitirá el conocimiento de lo «infinito» (v. 7). Ello no significa que para él los dos módulos versales, el regular y el libre, fueran idénticos, pues ya en sus aforismos señalaba propiedades diferentes para cada uno de estos recorridos rítmicos:

Suele creerse que verso «libre» es verso «descuidado». El verso libre admite, exije más arquitectura interna y externa que el regular. Además, no tolera ripio.

Si en el verso regular y rimado la medida la dan número y rima, en el libre, superior en esto, la dan inteligencia y gusto.

(No es necesario añadir que puede haber mal verso libre, como hay mal verso regular o, esperantistas sin ánjel, prosa toda ripio) ( $\$ 2304,379$ 380) ${ }^{14}$.

Por ello, en Diario el poeta se acerca al versolibrismo, pero manteniendo algunas de las características de la regulación formal anterior; él pretendía alzar una nueva «arquitectura» poética, que permitiera convertir al poema mismo en representación de la realidad que se estaba creando, ajena a cualquier pauta predeterminada; un trazado arquitectónico que transformara en «externa» la desnudez «interna» en la que el poeta se abisma con la seguridad de alcanzar la totalidad que la poesía constituye. No quería que «número» y «rima» resultaran ser los objetivos de la creación poemática, pero tampoco podía renunciar a las

14 Buena parte de la «crítica paralela» que Juan Ramón escribiera está contenida en sus aforismos, a los que destinaba Ideolojía, el cuarto volumen de Metamórfosis; ver Jiménez (1990). Se citará siempre indicando el número del aforismo y las páginas de esta edición. 
dos líneas esenciales de una «regularidad» rítmica que ha de ser, antes que nada, puro contenido poético. Quiere anteponer ahora, a esos efectos formales, la «intelijencia» y el «gusto»; a la primera le pedirá, en pocos meses, que le dé «el nombre exacto de las cosas»; el segundo concepto revelará la dimensión afectiva con que el poeta aguarda a convertirse en poema, como medio de ser finalmente la poesía misma ${ }^{15}$.

Por ello, cuando Juan Ramón se adentra en la poesía mediante los cauces del versolibrismo, lo hace desde un recorrido anterior que implica el dominio absoluto de todas las propiedades del verso regular. Sus aforismos señalan las continuas reflexiones a que Juan Ramón sometía su creación entera; ninguno de los principios de los que depende la «regularidad» versal le fue ajeno; sabía muy bien que el ritmo dependía del compás interior con que las sílabas fueran acentuándose:

El acento. Nuestro Bécquer, con el endecasílabo y el heptasílabo no crea una forma nueva. Lo que hizo fue darles un nuevo acento. En las traducciones, si se pierde el acento no queda nada $(\S 638,130)$.

Repárese en que secuencias de once y de siete sílabas serán las que predominen en la no tan «libre» versificación que se inicie con Diario; es la búsqueda de otra manera de «acentuar» las palabras, de abrirlas hacia ese ritmo interior que ha de conducir a la «desnudez» poética, como de inmediato señala:

Hay una inspiración del ritmo, del acento, como hay una inspiración del sentimiento y de la idea. Si no se aprovecha el instante, la idea o el sentimiento que se escriban, no estarán en su sitio, en su momento, en su luz ( $\S$ $639,130)$.

15 Como dirá más tarde en «La trasparencia, Dios, la trasparencia», el poema inaugural de Animal de fondo: «Eres la gracia libre, / la gloria del gustar, la eterna simpatía, / el gozo del temblor, la luminaria / del clariver, el fondo del amor, / el horizonte que no quita nada: / la trasparencia, dios, la trasparencia, / el uno al fin, dios ahora sólito en lo uno mío, / en el mundo que yo por ti y para ti he creado» (vv. 29-36). Y obsérvese de qué manera estos dos versos finales se adecuan a uno de los ritmos más seguros del poeta, el del alejandrino a la francesa, con dos hemistiquios de siete sílabas: «el/u/no-al/fin,/dios/aho/ra - só/li/to-en/lo-u/no/mí/o I en/el/mun/do/que/yo - por/ti-y/pa/ra/ti-he/crea/do", arrastrando el último una sorprendente estructura trocaica por las rupturas de sentido que provoca una acentuación que surge de la suma de la realidad creada (el «mundo») y de la identidad de ser de Juan Ramón («yo»). 


\section{LAS CLÁUSULAS INICIALES DE LOS POEMAS}

Ello es lo que provoca que los poemas de Diario arranquen de cláusulas versales plenamente regulares en la disposición métrica de sus acentos; suele, por lo común, establecerse un núcleo inicial de dos versos, con una identidad absoluta en sus proporciones métricas, pero que enseguida se despliega en una nueva indagación de ritmos; véase el comienzo del XXVI, escrito en las murallas de Cádiz el 29 de enero:

Aun cuando el mar es grande, o óo óo óo como es lo mismo todo, o óo óo óo

La extensión del mar reducida a la mismidad de su ser por obra y gracia de los dos heptasílabos que convierten en equivalentes las dos nociones. En otras ocasiones, se trata de dos endecasílabos, aunque alguno resulte escindido para formar una línea poética escalonada:

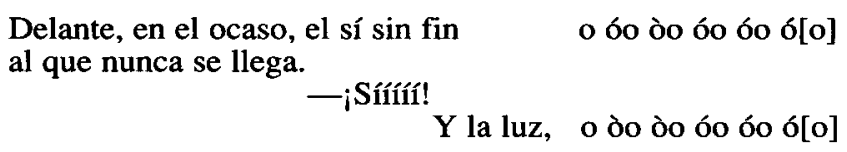

Los dos «síes» coinciden en la octava sílaba, del mismo modo que las oxítonas finales, con esa extraordinaria prolongación de una medida silábica, reproducen la ilimitada dimensión de una «luz» que, carente de «fin», le permite adentrarse en las honduras de su alma, como en este mismo texto lo pone de manifiesto:

en un lejos que el alma sabe alto y quiere creer lejos, sólo lejos... oo óoo óo òo óo

o óo òo óo óo óo

Descenso por la conciencia del poeta desde las rupturas de ritmo que estos dos endecasílabos finales enseñan para mostrar la unidad de las dos palabras acentuadas en sexta: esa «alma» que alcanza lo «lejos» (aun en su interior, en su mismo ser) en que debe «creer»; esta palabra, precisamente, es la que sufre la ruptura más violenta al perder el acento en la última sílaba y con él su identificación semántica con 
cualquier tipo de «creencia» lógica o racional; el ritmo acentual del verso construye «creer» no «creer», por cuanto se trata de abrirse a esa contradictoria lejanía de lo que se esconde en el interior (semejante al proceso aliterativo de las vocales del último endecasílabo: cuatro de las sílabas acentuadas arrastran el sonido de la misma vocal).

En «Víspera» (CLIII) vuelve a encontrarse un prodigioso arranque de endecasílabos, reducido progresivamente -y ello será una constante juanramoniana - de dos en dos sílabas en la secuencia de versos siguientes:

$\begin{array}{ll}\text { Ya, en el sol rojo y ópalo del muelle, } & \text { oo óoo bo do óo } \\ \text { entre el viento lloroso de esta tarde } & \text { oo óoo 6o óo óo } \\ \text { caliente y fresca de entretiempo, } & \text { o óo óo do óo } \\ \text { el barco, negro, espera. } & \text { o óo óo óo }\end{array}$

La compacta regularidad de los dos primeros versos se deshace en las secuencias trocaicas de los dos siguientes; el poeta reproduce el fenómeno del atardecer que él y Zenobia se hallan contemplando y que desea hacer equivalente a ese proceso de pérdida —como el de las sílabas de los vv. 3 y 4 que iba a suponer el regreso desde Nueva York. Los dáctilos de los dos primeros endecasílabos funden «sol» y «viento», del mismo modo que la acentuación de sexta consigue una misma realidad de la gama cromática y de esa líquida dimensión de las lágrimas. En esa posición central del endecasílabo, se inicia la «regulación» trocaica que luego los vv. 3 y 4 asumirán como forma de hacer patente — de integrar en el ser- la inevitable realidad de lo perdido.

\section{LA LONGITUD VERSAL}

El versolibrismo requiere ese juego con la dimensión física del verso, estos procesos de reducción silábica, a los que el poeta fía los sentidos del poema, que sólo son perceptibles cuando se aplican estas pautas de análisis métrico; en todo caso, Juan Ramón era consciente de los valores expresivos que propiciaba la longitud versal:

No se es más gran poeta por escribir más ancho o más largo. Al contrario, signo de gran poema es que el verso parezca más delgado y más corto de lo que es en realidad aun siendo estrecho y breve $(\$ 2782,451)$. 
Esto sólo puede conseguirse con los esquemas del versolibrismo, pero ello no significa que a esos versos se les obligue a perder su «regularidad» métrica; la conservan, pero encauzada hacia otros principios, como soporte de otra identidad poemática, incluso como medio de descubrimiento de nuevos procesos rítmicos; así sucede en «Nocturno» (CLXXII), del 14 de junio, que parece cumplida demostración del aforismo anterior; en él, los moldes versales descubren nuevas dimensiones, que requieren secuencias de versos apenas exploradas anteriormente por el poeta:

\author{
Tan inmenso como es joh mar! el cielo, \\ como es el mismo en todas partes, \\ puede el alma creerlo tan pequeño... \\ Enclavado a lo eterno eternamente \\ por las mismas estrellas, \\ ¡qué tranquilos sentimos, a su amparo, \\ el corazón, como en el sentimiento \\ de una noche, que siendo sólo nuestra madre, \\ fuera el mundo! \\ ¿Qué refugiados nos sentimos \\ bajo su breve infinidad definitiva!
}

6o óoo 6o óo óo o óo óo óo óo óo óoo óo óo óo òo óoo óo òo óo

500 óoo 60 óo óoo óo òo óo o òo óo òo òo óo oo óoo óo óo óo óo óo óo

10 óoo óo òo óo o òo óo òo óo òo óo

Afanosa búsqueda de troqueos, realizada en su plenitud en los vv. 2,7 y 11 , en donde se encierran los tres conceptos con los que Juan Ramón armará ya el resto de su producción poética: en el v. 2, eneasílabo, se presenta de nuevo esa mismidad con que el mar le enseñará a encontrarse, en cuanto creador, en cada uno de sus poemas; en el v. 7 se produce físicamente — pues tal es el valor de la aliteración de consonantes velares y nasales - la identificación entre «corazón» y «sentimiento»; en el v. 11, por fin, aun expresado como paradójica afirmación, se logra atrapar la realidad metafórica de ese mar, obstinado en ser siempre el mismo, para que el poeta haga lo propio con una poesía que lo contendrá, como el mar alberga a los que están en ese momento «refujiados» en su «infinidad». Ha de notarse que ninguno de estos tres versos coincide en su medida, aunque la «regularidad» de sus moldes la evidencie, de nuevo, el modo en que esos tres versos van aumentando de dos en dos sílabas, lo que implica una secuencia trocaica más en cada uno de ellos, de la misma manera que el mar ha ido abriéndose progresivamente para refugiarlos en la identidad desvelada.

Los nuevos versos de este «Nocturno» son los tridecasílabos octavo y undécimo que atrapan, en su interior, otros dos versos que, de sumarse, 
ofrecerían la misma densidad silábica de trece; esta circunstancia puede resultar casual, pero no la calculada progresión de las antítesis conseguida mediante la combinación de estas estructuras heterométricas; en otro aforismo lo explicaba:

Puede haber versos cortos pesados como un plomo y versos largos, larguísimos, más que largos, flojos como una paja $(\S 2866,464)$.

Alternancia de versos cortos y largos que responde a un trazado consciente de esa «arquitectura interna» del poema; en el verso libre, la medida del verso no la pone el poeta, la descubre el poema como ha sucedido en este caso ${ }^{16}$, en donde dos tridecasílabos se han abierto para cerrar en su interior al poeta y a Zenobia, aislados del mundo (el verso más breve y rotundo del texto), pero inmersos en el nuevo «refugio» que el mar representa; y puede decir «nos sentimos» porque el eneasílabo del verso décimo es consecuencia de la certidumbre revelada en el otro eneasílabo que formaba el segundo verso (encontrándose, además, los dos en posiciones simétricas: segundo y penúltimo del texto).

\section{LA DESNUDEZ FORMAL}

Juan Ramón, por tanto, aun siendo consciente como lo señalara, de que el molde de Diario era ese «verso libre» con el que quería atrapar las inmensidades a las que su conciencia se abría (nuevamente: el mar y el cielo, para alcanzar el amor), no puede renunciar a los compases o cadencias de la regularidad métrica, ya vinieran los versos dictados por ese impulso rítmico interior, ya surgieran de la combinación de secuencias heterométricas; sí, en cambio, salvo casos como el de «Soñando», pareció señalar un alejamiento del fenómeno de la rima, posiblemente para conseguir un verso de desnudez más pura, en el que la acumulación de la tensión rítmica en la última palabra no implicara otro tipo de asociaciones de significado poético; lo explicaba en varios aforismos:

16 En correspondencia con el aserto que A. Alonso (1979: 88) señalara como base de esta especial poética aplicada a P. Neruda: «Una sucesión de versos libres corresponde a una sucesión de unidades intuicionales o bien a un especial encabalgamiento de intuiciones exigido por el movimiento de la efusión sentimental». 
Aunque el «verso desnudo» mío es una «silva» sin consonante ni asonante (silva desnuda) es el único que se me representa, por su variedad numérica como tal.

El «romance» octosílabo, la «canción», la «estancia», el «arte menor», etc., sin rima, por su número exacto, por su paralelismo estrófico, no se me representan nunca como verso desnudo.

Al elejir mi verso desnudo bajo ese título, lo he hecho según mi inmediata representación $(\$ 3283,559)$.

«Verso desnudo» por fuera, pero recorrido internamente por una secuencia rítmica que es la que le presta su verdadero sentido, el que exige la fijación de esos esquemas de regularidad silábica; Juan Ramón, incluso, apunta a la combinación de endecasílabos y de heptasílabos («silva desnuda») como la más adecuada para lograr la plasmación del nuevo pensamiento poético que el Diario contiene. No le sirven ya los moldes estróficos ni la delimitación de paradigmas fijada por asonancias y consonancias; es otra «representación» poemática la que persigue, otra la «regularidad» que los versos anudan, pero con esquemas silábicos que garanticen ese metódico avance de un ritmo que ha de convertirse en desnudo contenido poético; para lograrlo, la rima no le sirve:

En la poesía, el verso en consonantes la tiene vestida; en asonantes a medio desnudar; libre, desnuda $(\$ 3427,588)$.

El verdadero ensayo del versolibrismo de Diario es de índole rítmica; la supresión de la rima coloca al poeta ante una nueva posibilidad de abrir el verso hacia nuevos procesos de significación, pues la trama de secuencias rítmicas no era anudada por una cadencia - consonante o asonante- final de sonidos, sino que exigía una proyección de la totalidad del verso en la secuencia siguiente; Juan Ramón construye una nueva identidad versal que se halla por encima de las pautas y principios de cualquier preceptiva, por supuesto, pero no de las necesidades que ese verso requiere. Juan Ramón habla de «verso libre» en un poemario en el que, de entrada, mezcla verso y prosa, un aspecto en el que no debe verse contradicción alguna:

La prosa de un poeta puede dar, a quien no entienda de verso, la medida y la calidad de su verso $(\S 2367,389){ }^{17}$.

17 Las relaciones entre los discursos formales de la prosa y del verso son objeto de consideración de una tesis doctoral de próxima lectura, realizada por M. ${ }^{\text {a }}$ Ángeles Sanz Manzano con el título de La prosa autobiográfica de Juan Ramón Jiménez: corpus textual y análisis crítico, en la Universidad de Alcalá. 
Es lo que significa «verso libre»: una nueva medida rítmica que le permita experimentar con la longitud versal e indagar con los períodos sintagmáticos del discurso prosístico. Y ello desde el mismo arranque, «Saludo del alba», en cuyo primer párrafo son reconocibles algunas de las secuencias rítmicas que, luego, en los poemas propician las cadencias isosilábicas ya reseñadas:

¡Cuida bien de este día! Este día es la vida, la esencia misma de la vida. En su leve transcurso se encierran todas las realidades y todas las variedades de tu existencia: el goce de crecer, la gloria de la acción y el esplendor de la hermosura (63).

Dos esquemas, el heptasilábico y el eneasilábico, acotan imágenes resueltas en el ideario poético que el libro desarrollará: «iCui/da/bien/ de- es/te/dí/a»: óo óoo óo; «Es/te/dí/a-es/la/vi/da»: óo óoo óo; «lae/sen/cia/mis/ma/de/la/vi/da»: o óo óo òo óo; se trata de un desarrollo que se repite al final del párrafo: «el/go/ce/de/cre/cer»: o óo òo ó[o], «la/ glo/ria/de/la-ac/ción»: o óo òo ó[o], «y-el/es/plen/dor/de/la-her/ $\mathrm{mo} / \mathrm{su} / \mathrm{ra}$ »: o òo óo òo óo; repárese, en fin, en que el modelo mixto de los dos primeros heptasílabos se acompasa en los dos últimos en una regulación trocaica, por las certidumbres que alcanza en esas cláusulas, procedentes de los primeros versículos: «día» se relaciona con «crecer», «vida» con «acción», para que «la esencia misma» de ese vivir consista en atrapar «el esplendor» de la belleza ${ }^{18}$.

\section{DEL «VERSO LIBRE» A LA «FORMA LIBRE»}

La medida, es cierto, no será isosilábica, aunque se atendrá a otros principios de desarrollo formal:

No hay verso largo ni corto; todo está en la manera de escribirlo o de imprimirlo ${ }^{19}$ (si no que lo diga un ciego). El romance de 8, por ej., escrito

18 Isabel Paraíso de Leal, controvertida estudiosa de Juan Ramón (1976a), aunque no del versolibrismo (1985), en uno de sus estudios iniciales sobre teoría rítmica indica (1976b: 119): «En la verdadera prosa poética es frecuente que los ritmos cuantitativos, acentual y timbral aparezcan, pero no lo hacen con periodicidad suficiente para que el esquema rítmico se imponga sobre el lingüístico».

19 Recuérdense los fenómenos de tipografía antes señalados. 
en verso de 16 parece otra cosa, pero ¿lo es? ¿Y deja de ser lo que es un verso de 45 por dividirlo en líneas de 5 ó 6 6 9? Por corto que sea un verso siempre es más largo que una semilla; por largo, más corto que el rabo de un ratón $(\S 2383,392)$.

Sin una medida pretendida, estas pautas de «regularidad» vienen exigidas por el propio contenido poemático, por esa «forma invisible» ( $\$$ $3500,601)$ que lograra fijar en uno de los aforismos más breves y más tensos de Ideolojía, que, sin duda, tuvo que precipitar el siguiente:

Forma poética: arquitectura ilójica $(\S 3501,601)$.

Tan «ilójica» como el mismo hecho de que se esté hablando de un «verso libre» que requiere principios de «regularidad métrica» (sin medida, sin rima, sin estrofa) para afirmarse:

Nada termina en forma sino en idea. Por eso la forma no termina nunca (§3502, 601).

Esto es lo que pretendía Juan Ramón con el Diario de 1916, construir unos moldes formales (el de cada verso por sí mismo, abriéndose a otras series similares) que no terminaran nunca, más que en el momento en que él los hubiera llenado de sí mismo, y a sí de ellos, como luego señalara en Animal de fondo, mediante otra plural combinación de esquemas rítmicos ${ }^{20}$ :

Todos mis moldes llenos [7 síl.]

estuvieron de ti; pero tú, ahora, [11 síl.]

no tienes molde, estás sin molde; eres la gracia [14 síl.]

que no admite sostén, [7 síl.]

que no admite corona, [7 síl.]

que corona y sostiene siendo ingrave. [11 síl.]

La «forma invisible», la dimensión «ingrave» del poema, abierto como la conciencia poética de que se nutre y a la que alimenta, en una

20 Ver I. Paraíso de Leal (1971). 
ejecución asombrosa de la realidad poemática a la que se accede; el convencimiento de Juan Ramón de que ha de escribir sin forma, pues tal es la dimensión a la que su ser se entrega, es la que le lleva a señalar con precisión el modo en que debe lograr borrar cualquier límite de esa expresividad esencial hacia la que tiende; al verso regular, el verso libre le quita la asonancia y la consonancia, pero conservando pautas de ordenación silábica como ya se ha visto; al verso libre le sucederá lo mismo, la mayor «libertad» del discurso de la prosa le llevará al poeta al convencimiento de que el verdadero ritmo poético sólo puede ser expresado mediante ese «molde sin molde» al que destinaba su poesía entera:

Cada día, ciego, señor de la lectura, voy separando menos el verso de la prosa, quiero decir, lo que llamamos verso y prosa. En realidad no hay verso, eso que solemos llamar verso, digo, línea aislada, los poetas. Todo es prosa, lo que llamamos prosa, digo, escritura seguida, sea el ritmo que fuere $(\$ 4111,752)$.

Es el primero de una serie de cinco aforismos que se titula precisamente «Ciego, señor de la lectura» y que puede servir para recoger conclusiones a este análisis de la evolución de las estructuras métricas y regulares que nacen en el Diario como asiento de la posterior poesía de Juan Ramón; cuando traza una línea divisoria entre el verso regular y el libre, se refiere de modo especial a la presencia de la rima, en cuanto aquella marca formal que imponía unos precisos enlaces de significado; el verso libre, al «liberarse» de esos paradigmas rítmicos, configura otras secuencias de «regularidad» de las que podrá prescindir cuando logre, tras Animal de fondo, convertirse él mismo en la forma poemática final; por ello, habla de una manera equivocada de ofrecer esa poesía anterior:

Señor de la lectura, ciego: ¡me equivoqué, me equivoqué en la forma de publicar mi verso libre! No, verso es sólo lo que termina en consonante o asonante. El verso libre que no es blanco es mejor imprimirlo como prosa, porque prosa ¿no es verso, siempre verso, y verso libre que no es blanco? $(\$ 4112,752)$.

En el «verso blanco» o suelto ${ }^{21}$, el isosilabismo afirma la identidad versal de un poema que merece ser impreso, entonces, de esa forma de

21 Y Juan Ramón construyó con esta forma algunos de sus más deslumbrantes poemas, como ocurre con la prodigiosa arquitectura de los diecisiete endecasílabos de «El otoñado» de La estación total. 
la que depende su significado ${ }^{22}$. Pero cuando el poeta ha cerrado su larga trayectoria, cuando ha logrado vaciarse por completo en todos esos moldes poemáticos, cuando recibe la plena totalidad de la dimensión creada, puede entonces, y desde dentro siempre, señalar la identidad de una forma que ha de ser siempre una sola:

No hay verso ni prosa, sólo lengua hablada o escrita en la forma que cada uno prefiera, pues cada uno tiene su lengua propia $(\$ 4114,752)$.

El último destino de todo poeta, convertirse en la imagen de la poesía que con su lengua acunara, lograr una «forma libre» final que fuera representación absoluta de una materia poemática que se reconoce en unos engarces formales, con el sentido paradójico de negar su propia virtualidad:

El poeta debe hacer olvidar la forma en que escribe; olvidar él que escribe en una forma $(\$ 3494,600)$.

Aunque para lograrlo haya tenido que recorrer un calculado camino que le llevara de la «libertad» de tratamiento del verso regular a la «regularidad» del verso libre.

\section{Referencias bibliográficas}

Alonso, A. (1979). Poesía y Estilo de Pablo Neruda [1954]. Barcelona: Edhasa.

Bousoño, C. (1970). Teoría de la expresión poética II. Madrid: Gredos.

COHEN, J. (1977). Estructura del lenguaje poético. Madrid: Gredos.

Domínguez Caparrós, J. (1988). Métrica y Poética. Bases para la Fundamentación de la Métrica en la Teoría Literaria Moderna. Madrid: UNED. Domínguez CAPARrós, J. (1993). Métrica española. Madrid: Síntesis.

22 «Porque el verso sin rima renuncia a uno de los elementos rítmicos, se hace necesario que esté más trabajado, notándose enseguida todo prosaísmo. De ahí que se tuviera por más difícil que el verso en el que hay rima», como recuerda J. Domínguez Caparrós (1999a: 487). 
DOMÍNGUEZ CAPARRós, J. (1999a). Diccionario de métrica española. Madrid: Alianza.

Domínguez CAPARrós, J. (1999b). «Métrica y poética en Rubén Darío». En Estudios de métrica. Madrid: UNED.

DomíngueZ ReY, A. (1987). El signo poético. Madrid: Playor.

GÓMEZ REDONDO, F. (1994). El lenguaje literario. Teoría y práctica. Madrid: Edaf.

Gómez Redondo, F. (1996). Juan Ramón Jiménez: teoría de una poética. Alcalá: Universidad.

JIMÉNEZ, J.R. (1994). Diario de un poeta reciencasado. Madrid: Visor.

JIMÉNEZ, J.R. (1946). «El modernismo poético en España e Hispanoamérica». En (1981) Prosas críticas, P. Gómez Bedate (ed.), 160-178. Madrid: Taurus.

JiMÉNEZ, J.R. (1990). Ideología (1897-1957). A. Sánchez Romeralo (ed.). Barcelona: Anthropos.

LóPEZ EstradA, F. (1969). Métrica española del siglo XX. Madrid: Gredos.

NAVARro TOMÁs, T. (1974). Métrica española. Reseña histórica y descripti$v a$. Madrid-Barcelona: Guadarrama-Labor.

Paraíso de Leal, I. (1971). «El verso libre de Juan Ramón Jiménez en Dios deseado y deseante». Revista de Filología Española 54, 253-269.

PARAíso De LeAl, I. (1976a). Juan Ramón Jiménez, vivencia y palabra. Madrid: Alhambra.

PARAíso DE LeAl, I. (1976b). Teoría del ritmo de la prosa. Barcelona: Planeta.

PaRaíso de Leal, I. (1985). El verso libre hispánico. Orígenes y corrientes. Madrid: Gredos. 